\title{
Dragon under the Blue Helmet: a quantitative analysis of China's motiva- tion for participation in UN peacekeeping operations
}

\author{
By Zhou Hang*
}

Research Assistant

China and Global Security Project, Stockholm International Peace Research Institute, Sweden

\begin{abstract}
From a staunch opponent to a reluctant supporter and now an active participant, China has dramatically transformed its perceptions and behavior in UN peacekeeping during the past three decades. China's shifting attitudes have attracted increasing academic attention. However, little quantitative study has been conducted to systematically explore China's motivations and selection criteria for participation in UN peacekeeping. It is therefore difficult to make generalizable claims. This essay focuses on China's participation from 1989 to 2010 and employs both logistic and linear regression models to examine the roles of China's economic, territorial, reputational interests and security policy in China's decision-making around peacekeeping. The statistical results show that the change in the PLA's operational orientation positively influences China's participation and China appears primarily to be a self-interested actor as to peacekeeping.
\end{abstract}

*Zhou Hang is a research assistant in the China and Global Security Project, Stockholm International Peace Research Institute (SIPRI). This is an abridged version of the author's Master thesis, completed as part of his master's degree in peace and conflict studies at the Department of Peace and Conflict Research, Uppsala University, Sweden 


\section{AFRICAN \\ EAST-ASIAN \\ AFFAIRS \\ THE CHINA MONITOR}

\section{Introduction}

From not participating in the voting on the United Nations Peacekeeping Operation (UNPKO) to supporting the majority of resolutions on it; from not paying any peacekeeping related dues to being the $7^{\text {th }}$ financial provider (UN Department of Peacekeeping Operations, 2012), China has dramatically shifted its attitudes on UNPKO in the past three decades. The UNPKO constitutes a new platform where the interaction between China and other international actors (the UN, host countries and other troop contributors) unfolds. In fact, China is currently the top troop contributor among the P-5 members.

China's increasing contribution could not come in a more timely fashion. The postCold War period has witnessed a worldwide surge of UNPKO deployment, mainly due to the re-ignition of civil wars which the US-Soviet rivalry used to keep a lid on. Both peacekeeping and conflict are becoming more complex. Nevertheless, while the UN peacekeeping regime is facing unprecedented challenges in terms of material, human and financial resources, the West remains ambivalent and distant at a moment when UNPKO is in urgent need of support and largely embodies a Western interpretation of peace, that is to say - peace operations become more about contributing to the construction of democratic polities, liberal economies and societies (Bellamy \& Williams, 2009: 44). This vacuum is gradually filled by the emerging countries, of which China is representative. In fact, UN Security-Generals Kofi Annan and Ban Ki -moon have both encouraged China to boost its contribution to peacekeeping (Ransom, 2008; UN Radio, 2004).

China's about-face from its originally recalcitrant position vìs-a-vìs UNPKO has attracted increasing attention from academia. While research on China's participation in UNPKO is growing, the bulk of literature concentrates itself methodologically on qualitative single-case studies, in which different, or sometimes conflicting arguments have been put forward to decrypt China's motivation. Through either focusing on China's role in one specific UNPKO (e.g. Hirono, 2011; Lanteigne, 2011) or mainly providing a historical overview of China's changing attitudes (e.g. He, 
2007; Wang \& Zuo, 2010), comparative case studies are also very limited. These methodological limitations are especially noticeable in literature published in Chinese, most of which is non-theoretical and essentially policyoriented (e.g. Guo, 2008; Wang \& Zuo, 2010; Zhang 2004). Without the support of statistical evidence, a number of explanations advanced by analysts to elucidate China's motivation could risk being drawn from the study of outliner cases; and therefore cannot be generalized. This paper aims at filling this methodological gap and unveiling Beijing's selection criteria for participating in UNPKO by conducting a quantitative study on the research question: why China sends its peacekeepers to some UNPKOs instead of others?

Based on Wallensteen's (2011) four models of major power politics - Kapitalpolitik, Geopolitik, Idealpolitik and Realpolitik, previous research on China's motivation for participation can be classified into four different analytical angles. Research based on the Kapitalpolitik and Idealpolitik models respectively claims that China's economic and reputational interests propel it to adopt a far more active stand on UN peacekeeping. Argument predicated on the Geopolitik model, on the other hand, asserts that China's participation is likely to be constrained by its concern over the implications of being involved in peacekeeping in territorial conflict, because of China's oft-challenged territorial claims over its own border areas and its unwillingness to set a precedent for international intervention in its own territory. Lastly, research based on the Realpolitik model takes an institution-based approach to concentrate on the role of the army in determining state participation in peacekeeping. It argues that a country is more likely to send peacekeepers - and probably a larger number - when its security policy is more externally-oriented.

Ordinary least square (OLS) and logistic regressions are used to test the hypotheses against samples that cover the UNPKOs between 1989 and $2010^{1}$. The problem of influential data seems to plague the statistical test and makes it difficult to draw conclusive statements. Tentative solutions of removing influential 


\section{AFRICAN \\ EAST-ASIAN \\ AFFAIRS \\ THE CHINA MONITOR}

data have been advanced to obtain reliable statistical results. The most significant result is concerned with the effect of China's security policy on its participation in peacekeeping. China was more likely to participate and send more peacekeepers after the introduction of an increasingly externally-oriented security policy introduced in 2005. The roles of economic and territorial interests are both pointed to by evidence from the statistical test, which suggests that China's decision on peacekeeping appears to be guided by self-interest. Besides, the number of battle-related deaths seems to be the worst predictor. It exerts no influence on whether or not China participates and how much contribution it makes.

The structure of this paper is as follows: the next session briefly presents the development of four hypotheses on China's motivation based on previous research. Following this is a short discussion of the research design which is then followed by the presentation of statistical results and the discussion of their implications. The paper concludes with a summary of the findings and some general policy implications that can be derived from the findings.

\section{Development of hypotheses}

This paper resorts to Wallensteen's four models of major power politics as a reference framework to categorize previous research on China's motivation for participation. Each model represents one area of interaction between major powers, from which change and potential conflict thereof may stem. Geopolitik and Realpolitik are rather self-explanatory - the former concerned with the politics of territory and the latter about the control of military power. Kapitalpolitik is devoted to the question of international trade and commerce, and Idealpolitik is related to the legitimacy of the state. Although these models were not initially formulated to analyze China's UN peacekeeping, they largely reflect the different perspectives of the majority of previous research on China's peacekeeping policy.

The majority of research in English on China's motives for participation is essentially realist and economic-centric. Various authors (Hellström 2009; Hirono \& Lan- 
teigne 2011; Kleine-Ahlbrandt \& Small 2008; Wu \& Talyor 2011; Zhao 2011) argue that China is in pursuit of economic interests through UN peacekeeping. UN peacekeeping is believed to help secure a favorable external environment for China's sustainable economic development - more specifically, in promoting trade, such as the export of goods and import of raw materials, with host countries. This argument leads to the first hypothesis:

Hypothesis 1: The probability that China sends its peacekeepers (China's contribution to UNPKO is higher/larger) if the trade volume between China and host countries is higher.

Beijing's support to UNPKO is bound by its flexibility on sovereignty and intervention. China's historical experience of being "semi-colonized" laid the foundation for China's rigid interpretation of sovereignty and the establishment of the Five Principles of Peaceful Coexistence - including non-interference in the internal affairs of other states and respect for territorial integrity and sovereignty - on which China's foreign policy is still in principle predicated (Carlson, 2005; He, 2007; Hirono \& Lanteigne, 2011; ICG, 2009; Taylor, 2008b: 136; Wu \& Taylor, 2008). China's oft-challenged territorial claims over the border areas obliges it to adhere to a traditional interpretation of sovereignty in case any compromise on the issue of sovereignty and intervention may backfire (Carlson 2005; Chen 2009: 158; Choedon, 2005: 54; Gill \& Reilly, 2000; He, 2007, Wu \& Taylor, 2011: 138). Many researchers (Carlson, 2005; Chen, 2009; Huang, 2011; Staehle, 2008) observe a softening of China's attitudes towards intervention and a process of China's gradual socialization into the UN peacekeeping regime in recent years; however, safeguarding territorial integrity still constitutes one of China's core interests and priorities; China is concerned that its consent to intrusive missions would have implications for its own territorial interests. The second hypothesis is therefore drawn as follows:

Hypothesis 2: The probability that China sends its peacekeepers/China's contribution to UNPKO is lower/smaller if a mission is established to keep peace in 


\section{AFRICAN \\ EAST-ASIAN \\ AFFAIRS \\ THE CHINA MONITOR}

\section{territorial conflict.}

With its political and economic role emerging on the global stage, China also draws increasing scrutiny, which makes it realize the importance of projecting a benign and positive image. This line of argument can also be considered interest-based, whereas it differs from the previous explanations in the way that it highlights China's ideational gains instead of material ones. Extensive literature both in English (Carlson, 2004: 11; He, 2007: 48-50; Hellström, 2009: 35-39; ICG, 2009: 12-14; Pang, 2005: 96; Taylor, 2008: 152; Thompson, 2005; Wu \& Taylor, 2011: 142; Zhao, 2011: 345) and in Chinese (Tang, 2002; Wang \& Zuo, 2010: 49-50; Zhang, 2004: 49; Zhang, 2009: 27; Zhao, 2009: 66; Zhong \& Wang, 2006: 36; Zhou \& Zhang, 2007: 59) claim that China's campaign in portraying itself as a responsible, cooperative and benign global power stimulates its recent enthusiasm on UNPKO. Ideally and arguably, contributing to peacekeeping in conflict that is more severe in terms of human suffering constitutes the best testimony to China's determination of being a "responsible global power" and it may also assist in boosting China's reputation on a larger scale. In addition, Chinese analysts, such as Zhang (2004: 47), criticize the West for turning a blind eye to conflict areas where peace is difficult to keep and where there is less strategic value but more risk. He highlights the humanitarian and idealist rationales behind China's decision. It implies that China's stance on peacekeeping is primarily guided by humanitarian concerns. Consequently, the third hypothesis is advanced.

Hypothesis 3: The probability that China sends its peacekeepers/China's contribution to UNPKO is higher/larger if the conflict concerned is more severe in terms of human suffering.

All the aforthmentioned hypotheses are drawn from the analytical perspective that considers China as a unitary actor. Velázquez's study (2010), disaggregating the unitary state into component institutions, concentrates on how the military and foreign policy circles influence a state's decision on peacekeeping and concludes that a country with an externally-oriented army is more likely to send peacekeeping troops 
into he field. An externally-oriented army, instead of shouldering major responsibility in maintaining public order and carrying out enforcement functions in the domestic setting - as the army with prevailing national security doctrines does - is likely to appeal to UNPKO, because UNPKO is in accordance with its doctrinal principle. Additionally, it will be especially sympathetic to UNPKO when there is no major external threat, as peacekeeping operations offer opportunity to garner field operation experiences in the absence of war (Velázquez, 2010). It is observed that the PLA's security doctrine has been evolving towards a more external orientation since the introduction of President Hu's new concept of "new historic missions" at the end of 2004 (Gill \& Huang, 2009: 15; Hirono \& Lanteigne, 2011: 250; Mulvenon, 2009). Hu's concept represents a natural outcome of, and response to, the challenges originating from China's everdeepening engagements and entanglements with the world. It also invests the PLA with a new broadened "operational orientation" that ranges "from defense of sea lines of communication for energy security to international peacekeeping operations" (Mulvenon, 2009: 9). The last hypothesis therefore is:

Hypothesis 4: The probability that China's contribution is higher/larger after 2005 compared to previous years.

\section{Research design}

The hypotheses are tested against the UNPKO missions between 1989 and 2010, regardless of whether the mission started or terminated within that period. The time frame is selected because China joined the UN Special Peacekeeping Committee in 1988. In the following year, China sent twenty civilian observers to the United Nations Transition Assistance Group (UNTAG) in Namibia for the first time. The dependent variable is measured in three different ways and therefore different regression models are employed accordingly. The logistic regression model is used when China's participation is measured by the dichotomous variable participation (parti) and the OLS regression model is employed when China's participation is gauged by the continuous variable contribution (ctb). The 


\section{AFRICAN \\ EAST-ASIAN \\ AFFAIRS \\ THE CHINA MONITOR}

dichotomous dependent variable Parti is coded as " 1 " indicating China's participation, and " 0 " otherwise ${ }^{2}$. Two continuous variables measuring China's contribution annually are employed, respectively Contribution in number (Ctb-num) and Contribution in percentage (Ctb-perc). Since the number of Chinese peacekeepers in a UN$\mathrm{PKO}$ varies month by month within one year, the peak month is selected for the variable $C t b$-num. For the variable $C t b$-perc, it is calculated by dividing the number of Chinese peacekeepers by the total UN peacekeepers from all the countries ${ }^{3}$.

Four independent variables are created. The variable Trade in million US dollars is used to measure the trade relationship between China and host countries. In the logistic regression, the variable is measured as the average trade volume between China and host countries in the three-year periods prior to the beginning of UNPKO or China's participation. In the linear regressions, the variable is measured as the annual trade volume between China and host countries one year preceding the annual observations for each UNPKO ${ }^{4}$. The variable Terricon is coded " 1 " if the incompatibility of conflict is concerned with territorial issues and coded " 0 " otherwise. I rely on the UCDP/PRIO Armed Conflict Dataset v.4-2011 (Gleditsch et al., 2002), which makes a distinction between "incompatibility concerning government" and "incompatibility concerning territory" to code this variable. The severity of a conflict is measured by the number of battle-related deaths. The variable Bdeath is measured as the aggregate battle-related death one year prior to the start of UNPKO or of China's participation in the logistic regression; and it is measured as the aggregate battle-related death one year preceding the annual observations of each UNPKO in the linear regression. Two sources are relied on - the PRIO Battle Deaths Dataset Version 3.0 (Lacina and Gledtisch, 2005), and the UCDP Battle-Related Deaths Dataset v.5-2011. The last independent variable is Secupo. President Hu assigned "new historic missions" to the PLA in the end of 2004. Hence, to measure the effect of the security doctrine, in the logistic regression, all the missions that had not ended by the end of 2004 or were initiated after December 31, 2004 are coded "1" and coded "0" otherwise. In the linear regressions, all the post-2005 annual observations of UNPKO are coded as "1" and " 0 " otherwise. To control any geographical differences, 
four dummy variables for the following regions are included: Asia/Pacific, Europe/Former Soviet Union; Middle East/Persian Gulf, and Africa. The Western Hemisphere is the baseline category.

\section{Empirics and analysis}

\section{Statistical results}

\section{(Table 1 on next page)}

\section{Findings for the hypotheses}

\section{Hypothesis 1 - Economic interests}

The statistical results in Table 1 provide no evidence to the first hypothesis, but this is probably due to the problem of small sample size and influential data. With some influential data removed, there is stronger evidence supporting the hypothesis.

The Trade variable generates only one significant coefficient out of the four regressions. Even more surprisingly, contrary to the theoretical expectation, three regressions indicate a negative relationship between bilateral trade and China's interests in UNPKO. One of the regressions from the linear regression with $C t b$-perc as dependent variable is $-5,078 \mathrm{E}-05$, significant at the $90 \%$ level.

Careful investigation is needed to interpret this counter-theoretical finding, given that it contradicts the conclusions of previous statistical research (Lawson, 2011; Lin-Greenberg, 2009), in which economic interest is identified as a motivating factor for China. To begin with, the size of samples for the logistic regressions, in which $n$ are around 50, is limited. This dearth of data may cause difficulty in producing significant coefficients. Meanwhile, theoretically, the transformation of China's security policy into being more externally-oriented can be ascribed to the increasing interdependency between China's economy and the external world; therefore, a correlation between the Trade and Secupo 


\begin{tabular}{|c|l}
\hline AFRICAN & Issue 3 \\
EAST-ASIAN & September 2013 \\
AFFAIRS & \\
\hline THE CHINAMONITOR & \\
\hline
\end{tabular}

Table 1. Determinants of China's participation in UNPKO,

Logistic and linear regressions

\begin{tabular}{|c|c|c|c|c|}
\hline \multirow{3}{*}{ Dependent Variables } & \multicolumn{2}{|c|}{ Logit Regression. } & \multicolumn{2}{|l|}{ Linear Regression } \\
\hline & parti & Parti & sbt-perc & cbt-numb $b^{*}$ \\
\hline & $\begin{array}{l}\text { Original } \\
\text { Sample }\end{array}$ & Adjusted Sample & Original Sample & Original Sample \\
\hline \multicolumn{5}{|l|}{ Independent Variables } \\
\hline Trade & $\mid-0,007$ & 0,025 & $-5,078^{E}-5^{*}$ & $-0,094$ \\
\hline Trade & $(0,942)$ & $(0,788)$ & $(0,079)$ & $(0,540)$ \\
\hline Territorial Conflict & $-2,123$ & $-1,132$ & $0,012^{* * *}$ & $-43,933 *$ \\
\hline Terricon & $(0,205)$ & $(0,402)$ & $(0,006)$ & $(0,054)$ \\
\hline Deaths. & $4,414^{\mathrm{E}}-4$ & 0,001 & $9.815^{\mathrm{E}}-6$ & $0,293^{* *}$ \\
\hline Bdeath & $(0,915)$ & $(0,820)$ & $(0,657)$ & $(0,013)$ \\
\hline Security Policy & $3,83^{* \star *}$ & $2,632^{* * *}$ & $0,006^{* *}$ & $114,134 * * *$ \\
\hline Secupe & $(0,006)$ & $(0,008)$ & $(0,041)$ & $(0,000)$ \\
\hline AsiaPacific & 2,661 & 2,047 & $-0,006$ & 5,565 \\
\hline$A P$ & $(0,22)$ & $(0,296)$ & $(0,468)$ & $(0,898)$ \\
\hline EuropeFormer Soviet Union & 0,374 & 0,495 & $-0,016^{* *}$ & 3,259 \\
\hline Eusu & $(0,868)$ & $(0,793)$ & $(0,020)$ & $(0,931)$ \\
\hline Africa & 2,194 & 1,705 & $0,012^{* *}$ & 38,942 \\
\hline Aftica & $(0,175)$ & $(0,205)$ & $(0,043)$ & $(0,218)$ \\
\hline Middle East & 3,128 & 1,255 & $-0,010$ & 33,840 \\
\hline$M E$ & $(0,251)$ & $(0,548)$ & $(0,196)$ & $(0,396)$ \\
\hline Constant & $-2,964^{*}$ & $-2,496^{* *}$ & 0,005 & 23,857 \\
\hline & $(0,056)$ & $(0,05)$ & $(0,335)$ & $(0,647)$ \\
\hline N & 48 & 53 & 281 & 281 \\
\hline$R 2$ & 0,571 & 0,434 & 0,194 & 0,259 \\
\hline Adjusted $R 2$ & & & 0,170 & 0,238 \\
\hline
\end{tabular}

Significance levels: 99\%***; 95\% **; 90\%* (Sig values are in parentheses; coefficients that are significant at least at the $90 \%$ significance level are in bold)

(C) Centre for Chinese Studies, Stellenbosch University All Rights Reserved.

http://aeaa.journals.ac.za 
variable may exist and potentially gives rise to multicollinearity and renders the Trade coefficient insignificant.

However, when the Secupo variable was dropped from all the regressions, the Trade coefficients did not gain significance and the co-linearity diagnostics showed acceptable Tolerance values, which ruled out the possibility of multi colinearity ${ }^{6}$. Lastly, "the method of least-squares is very sensitive to the structure of the data and can be markedly influenced by one or a few unusual observations" (Fox, 2012). As the dependent variables Ctb-perc and Ctb-num both measure China's contribution to UNPKO annually, peacekeeping operations that last for a long period are likely to have over-proportional influence upon the statistical model. A look at the partial regression plots of both linear models reveals problems of potential influential data ${ }^{7}$. In both equations, the culprits appear to be some observations drawn from the United Nations Military Observer Group in India and Pakistan (UNMOGIP). China has not participated in this mission and the annual observations of this mission from 2005 to 2010 are coded with an enormous amount of trade volume between China, India and Pakistan, which seems to bias the shape of slopes ${ }^{8}$. A tentative plan to drop these six observations generates the following results:

Table 2. Trade coefficients after removing the suspected influential data from UNMOGIP

The Trade coefficients in the linear regressions change considerably. For the

\begin{tabular}{|l|ll|}
\hline $\begin{array}{l}\text { Dependent Variables } \\
\text { Independent Variables }\end{array}$ & $\begin{array}{l}\text { LinearRegression } \\
\text { cbt-perc }\end{array}$ & cbt-numb \\
\hline Trade & $-1,4 \mathrm{E}-4$ & $\mathbf{2 , 9 9 0 * * * *}$ \\
Trade & $(0,225)$ & $\mathbf{( 0 , 0 0 0 )}$ \\
$N$ & & 275 \\
$R 2$ & 275 & 0,335 \\
\hline
\end{tabular}

Significance levels: $99 \% * * * ; 95 \% * * ; 90 \% *$ 


\section{AFRICAN \\ EAST-ASIAN \\ AFFAIRS \\ THE CHINA MONITOR}

linear model with Ctb-num as dependent variable, the Trade coefficient becomes positive, significant at the $99 \%$ level and points to the theoretically-expected direction. It means that when controlling for other variables, with a ten million US dollar increase of the trade volume between China and host countries, Beijing sends approximately 30 more peacekeepers. The Trade coefficient in the other regression still does not have the predicted sign, but loses significance.

The identification of influential data averts a premature conclusion, predicated on the statistical results in Table 1, that there might be signs of a negative relationship between trade volume and China's participation. While the insignificant results from the logistic regressions possibly indicate that economic interests measured by trade volume is not likely to have influence on China's willingness of participation, the significant coefficient obtained from the linear regression - when some influential data is removed - suggests that once China decides to participate in UNPKO, it is likely to send more peacekeepers to host countries where it maintains strong economic relationships.

\section{Hypothesis 2 - Normative concerns and territorial interests}

There is some evidence from the regression analysis supporting this hypothesis. The Terricon variable is the proper sign (negative) but does not pass the significance test in both logistic regressions. This result can be interpreted as follows: the incompatibility of conflict concerning territory is not likely to affect whether or not China participates in UNPKO. For the linear regression, the Terricon variable reveals some ambiguous results. With Cbt-num as dependent variable, the Terricon coefficient is 43,933 , significant at the $90 \%$ level. Pointing to a theoretically-expected direction, it implies that when controlling for other variables, China downsizes its peacekeeper contribution by around 44 persons if UNPKO operates in territorial conflict. However, the linear regression taking Cbt-perc as dependent variable results in a Terricon coefficient significant at the $99 \%$ level, pointing to the opposite direction. It is 0,012 indicating that the percentage of Chinese peacekeepers in territorial conflict is $1.2 \%$ higher than that in non-territorial conflict when controlling for other variables. This 
outcome suggests that while China reduces the number of Chinese peacekeepers in a territorial conflict, the percentages that it occupies actually increase ${ }^{9}$.

A closer look at the data casts light on this seemingly contradictory result. For instance, from 2005 to 2009, the number of Chinese peacekeepers in the United Nations Organization Mission in the Democratic Republic of the Congo (MONUC, a non-territorial conflict) ranged from 230 to 234 annually, representing only $1.27 \%$ to $1.64 \%$ of the total mission personnel, while during the same period, the United Nations Mission for the Referendum in Western Sahara (MINURSO, a territorial conflict) receives only 13 to 21 Chinese peacekeepers, occupying a much larger percentage $-5.7 \%$ to $9.1 \%$. Moving from a nonterritorial conflict (MONUC) to a territorial one (MINURSO), the Ctb-num observes a huge decrease of China's troop contribution, whereas the Ctb-perc marks an augmentation. Evidently, the size of the peacekeeping mission and the contribution that other countries make - while exerting no influence on the $C t b$ num variable - can greatly influence the value of Ctb-perc. Consequently, while both measurements gauge China's contribution, their coding values of the same case can lead to completely different conclusions regarding the relationship between territorial conflicts and China's contribution. However, it is reasonable to take both values into account, as the seemingly contradictory results may signify the necessity to put into perspective China's concern over getting involved in peacekeeping in territorial disputes. While China sends less peacekeepers to territorial conflicts, other countries seem to also follow the same pattern - possibly downsizing their contributions on an even larger scale than China, thus making China's contribution increase in terms of percentage. This interpretation is more understandable, when considering most of the current troop contributors are developing countries - which are generally supporters of the Westphalian interpretation of sovereignty and may find sending troops to intervene in other country's territorial conflict against their normative understanding of sovereignty. 


\section{AFRICAN \\ EAST-ASIAN \\ AFFAIRS \\ THE CHINA MONITOR}

Overall, it can be argued that, considering its troop contribution to territorial conflicts is significantly less, China is afraid that its decision to intervene in territorial conflicts may boomerang and compromise its own territorial interests. However, this concern is unlikely to fully encumber its latitude to act as to peacekeeping. Probably due to its increasing confidence that comes along with its growing national capabilities, China is willing to put its concern on the back burner to pursue other more important goals.

\section{Hypothesis 3 - Responsible global power}

The problem of influential data makes the minimal supportive evidence found in Table 1 inconclusive and there is no proof in favor of this hypothesis after a tentative plan to remove the influential data.

While the Bdeath coefficients all point in the expected direction, only one gains significance. The statistical test using Parti as dependent variable does not produce a single significant Bdeath coefficient. This lack of significance has to be interpreted with caution due to the small sample size; however, such a result seems to indicate that the severity of a conflict measured by battle-related deaths exerts no impact on the probability of China's participation in UNPKO. The Bdeath coefficient for the linear regression with Ctb-num as dependent variable is 0,293, significant at the $95 \%$ level, denoting that controlling for other variables, when there is an increase of 10,000 battle-related deaths, China sends about three more peacekeepers. A look at the partial-regression plot and the scatter-plot of standardized DFbeta of this coefficient reveals that influential data may exist. Three observations could have overproportional effects on the Bdeath coefficient in this Ctb-num regression: the observation of the United Nations Iran-Iraq Military Observer Group (UNIIMOG) and two observations of the United Nations Transitional Authority in Cambodia (UNTAC). As shown in Table 3, it remains positive $(0,111)$, but becomes insignificant when these three observations are dropped. 
Table 3. Bdeath coefficients after removing the suspected influential data from UNTAC and UNIIMOG

\begin{tabular}{|l|ll|}
\hline $\begin{array}{l}\text { Dependent Variables } \\
\text { Independent Variables }\end{array}$ & $\begin{array}{ll}\text { LinearRegression } \\
\text { cbt-perc }\end{array}$ & cbt-numb \\
\hline Battle-RelatedDeaths & $-2,160 \mathrm{E}-5$ & 0,111 \\
Bdeath & $(0,322)$ & $(0,520)$ \\
& & \\
$N$ & 280 & 278 \\
$R 2$ & 0,229 & 0,273 \\
\hline
\end{tabular}

Significance levels: $99 \% * * * ; 95 \% * * ; 90 \% *$

Meanwhile, Table 1 displays that when China's participation is measured in percentage, there is no significant result. The influence of unusual data is again detected and the culprit appears to be one observation (Year 1992) of the UNTAC, which greatly magnifies the size of effect of Bdeath on Ctm-perc. Table 3 illustrates that the Bdeath coefficient in this regression becomes negative, but still insignificant when this observation is omitted. Overall, the statistical results relating to the Bdeath variable in the original sample are likely to be biased by influential data. A tentative solution to remove the unusual observations in both linear regressions does not generate any significant Bdeath coefficient. Hence, hypothesis 3 does not appear to garner empirical support.

However, it is difficult to fully refute China's claim of being a "responsible great power" only based on the lack of significance found here regarding the hypothesis 3 . Previous research (Gilligan and Stedman 2003; Fortna 2004 \& 2008) shows that the UN tends to intervene in more "difficult" cases. Following this line of argument, as long as China does not veto a UNPKO, all the established UNPKOs can be consid- 


\section{AFRICAN \\ EAST-ASIAN \\ AFFAIRS \\ THE CHINA MONITOR}

ered as a piece of evidence supporting China's claim, because it is true by definition that any decision to initiate UNPKO entails China' support with its P-5 membership. However, troop commitment is different from political commitment; and constitutes a more persuasive signal of being a responsible power. Hence, the non-significant result relating to hypothesis 3 may be more appropriately interpreted as follows: Beijing may think that its claim of being a "responsible global power" has already been convincingly evidenced by its political commitment. When it comes to dispatching troops and getting involved on the ground level - a sign of deeper commitment to its claim, China - probably like other countries - becomes more cautious. A high level of battle-related deaths could be an indication that the peacekeeping on the field involves a high degree of risk and complexity. The desire to be seen as a "responsible great power" alone does not guarantee China's willingness to take risk and send troops to conflicts with high level of battle-related deaths.

\section{Hypothesis 4 - Security policy}

This hypothesis finds strong statistical evidence from the regression analysis. The Secupo variable is the only one that gains significance across all the regressions. The logistic regressions produce coefficients 3.83 and 2,632 from the original and adjusted sample. Both are significant at the $99 \%$ level, implying that China's willingness of participation has considerably augmented since 2005. The Securpo coefficient in the linear regression taking Ctb-num as dependent variable is 114,134 , significant at the $99 \%$ level, suggesting that when controlling for other variables, a mission receives approximately 114 more Chinese peacekeepers in the post-2005 period than before. Similar results are obtained from the linear model measuring China's contribution as a function of the percentage of Chinese peacekeepers. The coefficient 0,006 passes the significant test at the $95 \%$ level $^{10}$.

The consistent statistical finding related to the Secupo variable is the strongest result in this study and indicates that since the PLA's operational orientation became no longer confined to internal security and evolved to be more externally-focused, China is more disposed to participate in UNPKO and makes more substantial troop con- 
tributions. However, contrary to the causal direction proposed by hypothesis 4 , it is also reasonable to argue that the dependent variable - China's participation in UNPKO - could be part of the reason why China's security policy becomes increasingly externally-oriented in the first place. It is worth mentioning here Mulvenon's study (2009: 2), in which he asserts in a general manner that the change in the PLA's security policy is compelled by "China's increasingly global interests and entanglements." However, it remains unspecified what the "global interests and entanglements" exactly refer to. In this case, the best remedy would be to conduct a more detailed process-tracing case study on the factors conducive to the transformation in the PLA's operational orientation. If the transformation is mainly due to, for instance, China's globalized economic interests then the causal effect of security policy on China's participation in UNPKO can be better evidenced by the statistical finding. Hence, further research is necessitated in order to make fully conclusive statement.

\section{Control variable analysis - Geographical differences}

The control variables shed some extra light on the pattern of Chinese UN peacekeeping, with some evidence of regional bias in favor of Africa.

In the logistic regressions, the constant coefficients are significantly negative, indicating China is less likely to participate in missions to the Western Hemisphere. In fact, China has only participated in the mission to Haiti out of eight missions in this region. However, the significant result may not be reliable due to the small sample size. The coefficients on the European and Former Soviet Union dummy $(-0,016)$ and the Africa dummy $(0,012)$ are also significant, when Ctb-perc is the dependent variable. The percentage of Chinese peacekeepers is significantly lower in missions to the European and Former Soviet Union countries. Until 2010, China has only participated in two missions to this region, sending 15 peacekeepers to the United Nations Mission in Bosnia and Herzegovina (UNMIBH) and 20 peacekeepers to the United Nations Interim Administration Mission in Kosovo (UNMIK). These contributions are very small, giv- 


\section{AFRICAN \\ EAST-ASIAN \\ AFFAIRS \\ THE CHINA MONITOR}

en that UNMIBH usually consists of 2000 peacekeepers and UNMIK comprises $1500^{11}$. The results, however, need to be treated with caution, because the tolerance value of the Eusu variable does not pass the threshold of 2. This is possibly due to a bivariate correlation between the Eusu and Terricon variables, since the majority of cases coded as Eusu is also coded as territorial conflict. Therefore, no conclusive statement can be drawn. However, all these preliminary results may indicate that China exhibits more circumspection on its decision to dispatch troops if the target country is primarily in the lap of other major powers. The opposite trend is detected with respect to missions in Africa, in which China shows propensity for comprising a larger proportion of the UN troops. And if one does not apply a strict rule of thumb, the statistical result on the Africa coefficient appears to be reliable, with a tolerance value $0,208^{12}$. This finding confirms some researchers' claim (Butts \& Bankus, 2009; Kleine-Ahlbrandt \& Small, 2008; Wu \& Talyor, 2011) that China accords particular attention to peacekeeping in Africa.

\section{An African sample}

On the Forum of China-Africa Cooperation, Chinese leaders promise that China would continue to take an active part in UNPKO to promote peace and conflict resolution on the continent. Luck (cited in Lynch, 2006) goes further to suggest that Africa is a "bellwether" for Chinese attitudes on intervention. Therefore, China may arguably have a more coherent, focused and proactive peacekeeping policy towards Africa; missions to Africa constitute a good sub-sample for gauging to what extent China's policy on peacekeeping can be active and progressive ${ }^{13}$. Statistical results from the multivariate linear regressions against the African sample are displayed in Table 6. At large, the previous comments on the four hypotheses are still germane when it comes more specifically to China's peacekeeping efforts in Africa.

The results from this sub-sample corroborates that the problem of influential data arises as to the Trade variable in the original sample and that China is more likely to send more peacekeepers to African countries with which it has more substantial trade relationship. In this sub-sample, the Trade coefficients are significant in both regres- 
Table 4. Results of the African sample ${ }^{14}$

\begin{tabular}{|c|c|c|}
\hline $\begin{array}{l}\text { Dependent Variables } \\
\text { Independent Variables }\end{array}$ & $\begin{array}{l}\text { Linear Regressio } \\
\text { cbt-perc } \\
\text { African Mission }\end{array}$ & $\begin{array}{l}c b t-n u m b \\
\text { African Mission }\end{array}$ \\
\hline Trade & $0,001^{*}$ & $8,402^{* \star *}$ \\
\hline Trade & $(0,06)$ & $(0,003)$ \\
\hline Territorial Conflict & $0,051^{* \pi *}$ & $-21,705$ \\
\hline Terricon & $(0,000)$ & $(0,641)$ \\
\hline Deaths & $-1,33, E_{-4} 4^{* * *}$ & 0,194 \\
\hline Bdeath & $(0,008)$ & $(0,498)$ \\
\hline Security Policy & $-0,004$ & $122,123^{* * *}$ \\
\hline Secupo & $(0,537)$ & $(0,001)$ \\
\hline Power Status & $-0,063^{* * *}$ & $-74,345$ \\
\hline Status & $(0,000)$ & $(0,261)$ \\
\hline Intermediary Intervention & $-0,056^{* *}$ & $-193,156$ \\
\hline Interme & $(0,018)$ & $(0,162)$ \\
\hline Constant & $\begin{array}{l}0,024^{* \dot{*} *} \\
(0,000)\end{array}$ & $\begin{array}{l}17,811 \\
(0,490)\end{array}$ \\
\hline$N$ & 98 & 98 \\
\hline$R 2$ & 0,183 & 0,405 \\
\hline Adjusted R2 & 0,147 & 0,366 \\
\hline
\end{tabular}

Significance levels: $99 \% * * * ; 95 \% * * ; 90 \% *$ 


\section{AFRICAN \\ EAST-ASIAN \\ AFFAIRS \\ THE CHINA MONITOR}

sions, which confirms, to certain degree, some researchers' (Butts \& Bankus, 2009; Kleine-Ahlbrandt \& Small, 2008; Wu \& Talyor, 2011) mercantilist interpretation that China's peacekeeping engagement in Africa is mainly driven by its economic interests.

Secondly, when the sample is restricted to the African missions, conflicts that are more severe in terms of battle-related death do not appear to receive more or less Chinese peacekeepers, if anything, there is evidence indicating that the proportion of Chinese peacekeeper seems to be in decline in severe conflicts. This finding is generally in line with the previous statement pertaining to hypothesis 3 that Beijing acts prudently when it comes to troop contribution. Dispatching troops to more deadly conflicts does not seem to be the most cost-effective way for China to demonstrate their commitment to being a responsible power.

Additionally, the most interesting statistical finding is concerned with the Terricon variable and reflects how proactive China can be as to peacekeeping. The coefficient is in the right sign (negative) when China's contribution is measured in number, but does not pass the significance test for the first time in this study. However it remains positive and significant in the linear regression with $C t b$-perc as dependent variable. The number of Chinese peacekeepers in African missions is not influenced by the incompatibility of conflict concerning territory; there is even evidence that the percentage of Chinese peacekeepers would increase if missions operated in territorial conflicts. Taking the significant results on the Trade variable into account, it may be claimed that regarding China's decision-making on peacekeeping in Africa, economic rationale overrides China's concern over its involvement in the conflict resolution of territorial dispute. This finding illuminates that under certain circumstances - for instance, in pursuit of economic interests - China may deviate from being an obstinate defender of the traditional interpretation of sovereignty

Lastly, the Secupo variable shows similar results to those in Table 4 and suggests that China's emerging role in Africa should also be put into perspective. The statistical finding indicates that during the post-2005 period, the number of Chinese peace- 
keepers in missions to Africa has grown considerably; but the proportion of peacekeepers that China takes in these missions remains basically unchanged throughout the years. Since the size of UN missions in Africa appears to have expanded in recent years, the increasing number of Chinese peacekeepers that African countries host during the post-2005 period does not necessarily imply that the growth of China's troop contribution on the continent is out of proportion. Quite the contrary, the share of Chinese peacekeepers in missions to Africa has remained stable. By and large, the rising distribution of Chinese peacekeepers to Africa follows the broader pattern in which the UN sends the bulk of its personnel. that is to say, as the UN accords increasing importance to the conflict resolution efforts in Africa and enlarges the size of missions, troop contributors including China thereupon boost their troop contribution. Hence, China probably does not act more responsibly than other countries; but it does not drag behind either. Regarding the Status and Interme variables, they gain significance when China's contribution is measured in percentage. However, the limited number of observations for these two variables precludes the possibility of drawing substantial inference ${ }^{15}$.

\section{Conclusion}

While increasing its troop contribution, China remains selective in terms of which missions it sends peacekeepers. Previous research indicates that China's economic, territorial, reputational and security policy interests could exert influence on China's decision to send troops. This study draws hypotheses from these theoretical arguments and runs a mix of OLS and logistics regressions against samples composed of UNPKOs (1989-2010) to explore China's motivation for participation in UN peacekeeping.

The strongest result is that the shift in China's security policy towards the externally-oriented end has a significant and positive impact on China's willingness to participate in missions and contribute troops. There is also some evidence indicating that host countries which maintain higher trade volumes with 


\section{AFRICAN \\ EAST-ASIAN \\ AFFAIRS \\ THE CHINA MONITOR}

China tend to receive a larger number of Chinese peacekeepers. China's territorial interest and normative concern over intervention are found to reduce its contribution, with Chinese peacekeepers featuring significantly less in territorial conflicts. However, other troop contributors probably share the same kind of concern. Finally, the answer to the question of whether participating in UNPKO shows that China is a responsible power may not be as simple as it appears to be. It depends on whether one talks about China's political or troop commitment to UNPKO; and it also depends on how much troop contribution that the international community expects from China. Regarding the troop commitment, China is no more likely to display stronger willingness to participate or contribute more peacekeepers in deadly conflict. However, there is also evidence indicating that the surge of Chinese peacekeepers in recent years by and large follows the expansion in the size of UNPKO. The exponential growth both in the number and size of peacekeeping missions places the UN under huge stress. Hence the increasing number of Chinese peacekeepers on the ground could also be seen as a sign of China's commitment to being a responsible player.

China's peacekeeping behavior constitutes a micro-cosmos to observe the increasing complexity of China's diplomatic and policy maneuvers in its path from being a third-world developing country to a major power. The finding in this thesis generally shows that as to peacekeeping participation, China is primarily a self-interested, rational actor who is undertaking a deliberate cost-benefit analysis and strives to strike a delicate balance between competing interests - each of which potentially requires different policy responses. Rather than being static, China's interpretation on sovereignty is also maneuverable. Its flexibility on sovereignty and intervention is primarily bound by the security situation in China's border areas and whether other national imperatives come into play, such as pursuing economic development. This is markedly illustrated by China's peacekeeping policy in Africa, as economic rational tends to outweigh China's normative concern and territorial interests. Hence, in practice, rather than being bridled by some rigid principles, China's decision on peacekeeping is primarily made on a case-by-case basis. Based on the result from this study, it can 
also be predicted that as long as China's security policy remains (or becomes more) externally-oriented - which implies that there is no major internal security threat, for instance, in its border areas - and China's economic interdependency with the world continues to deepen, China's contribution of peacekeepers is likely to be remain stable and probably rise in the foreseeable future. In general, this is a piece of good news that the shorthanded UN and DPKO are delighted to hear, whilst possibly making no substantial difference to host countries that are not on the African continent and/or without substantial economic relationship with China. Over a longer period of time, it remains to be seen whether China will follow other western powers' path to shift its troop contribution to "hybrid" or non-UN peace operations.

\section{Endnotes}

1. Ordinary least-squares (OLS) regression is used to predict values of a continuous dependent_ variable using one or more explanatory variables and gauge the strength of the relationship between these variables. Logistic regression in general is used to predict a dichotomous/binary outcome.

2. In some UNPKOs, China participated in a later stage rather than from the very beginning of a mission. In order to capture such a dynamic, this article follows Lawson's research design (2011: 27). He considers those UNPKOs to which China did not send its peacekeepers until at least one year after the beginning of the operation as separate cases (UNIBH, MONUC, UNFIL, UNMIK). For instance, the UNMIK in Kosovo operated from 1999 till present. But China did not send its peacekeepers to Kosovo until 2004 and withdrew its participation again in 2009. Therefore, the 1999-2003 and 2009-2010 periods are both coded as " 0 " because of China's non-participation, while the 2004-2008 period is coded as " 1 ". In order to avoid statistical biases that are likely to be provoked by this dou- 


\section{AFRICAN \\ EAST-ASIAN \\ AFFAIRS \\ THE CHINA MONITOR}

ble or triple counting of a UNPKO, the logistic regression is run against a sample that does not treat the above-mentioned missions as separate cases.

3. Data related to all these three independent variables are collected from the Archive of Troop and Police Contributors.

4. All the monetary values are converted to constant US dollars (in 2003 dollars). Data on bilateral trade is primarily collected from the China Statistical Yearbook (1986-2011). For a very limited number of cases, data from the International Monetary Fund's (IMF) Direction of Trades statistics database is also used.

5. I also tried to convert this variable into a 0-100 scale; however, the statistical results remained unchanged.

6. As a rule of thumb, when the tolerance value is smaller than $0.2 / 0.3$, one should be concerned with multi co-linearity. multi co-linearity does not appear to exist in all the regressions with respect to all the independent variables.

7. This study mainly relies on the partial regression plot and scatterplot of standardized DFbeta to detect influential data. A partial regression plot shows the marginal role of a variable in the model, given that all the other independent variables are already in the model. Dfbeta is a t-test for the difference of the $b$ -coefficient with and without a certain observation.

8. The trade volume of these observations (2005-2010) stands outside around three standard deviations $(51,8)$ from the mean value $(12,2)$ of the Trade variable.

9. According to the partial regression plot and scatterplot of standardized DFbeta of the coefficient Terricon in both linear regressions, the problem of influential data appears to be minor.

10. According to the partial regression plot and scatterplot of standardized DFbeta of the coefficient Secupo in both linear regressions, the problem of influential 
data appears to be minor.

11. In 2011, another mission to Europe, UNFICYP (Cyprus), received, for the first time, 2 Chinese peacekeepers. However, this data is located outside the time-frame of this thesis.

12. A less strict rule of thumb: one does not need to be concerned when the tolerance value is bigger than 2 .

13. This sub-sample is only used to run the linear regressions because the sample size for the logistic regressions is too limited to establish a subsample.

14. As previously discussed, the problm of influential data often generates nonsignificant results or significant results in signs that are contrary to theoretical expectations in this study. In fact, influential data may hint at the necessity of model re-specification (Fox: 2012). Influential data from UNMOGIP shows that international-level factors, such as the power status of the target state, are helpful in construing China's troop contribution. It is highly improbable that the gigantic bilateral trade would impel China to send peacekeepers to India, because India is a major regional increasingly global - power. Meanwhile, some observations from UNTAC are considered as influential data. A preliminary study of the peace process in Cambodia shows that China is probably more likely to commit troops to solve conflict if it has previously intervened as intermediary. Therefore, two new variables Power Status (Status) and Intermediary Intervention (Interme) are included to run robustness checks. The results of robustness checks show that the previous statements pertaining to the four hypotheses still hold. These two variables are also included in regression analysis against the African sample.

15. Based on the list of major power coded by Mullenbach (2005: 542) to scruti- 


\section{AFRICAN \\ EAST-ASIAN \\ AFFAIRS \\ THE CHINA MONITOR}

nize the effect of the power status of target state on the establishment of thirdparty peacekeeping mission, only three observations can be coded as involving major power in the sample of this study. These are respectively, UNMEE, UNMOGIP and UNIIMOG. Meanwhile, Cambodia and Sudan appear to be the only two cases in which China played a role as intermediary.

\section{Bibliography}

Bellamy, A.J. and Williams, P.D. 2009. The West and Contemporary Peace Operations. Journal of Peace Research 46(1): 39-57.

Butts, K.H. and Bankus, B. 2009. China's Pursuit of Africa's Natural Resources. Centre for Strategic Leadership, Collins Center Study, US Army War. Available: http://www.csl.army.mil/usacsl/publications/ CCS1_09_ChinasPursuitofAfricasNaturalResources.pdf. [2012, May 16].

Carlson, A. 2004. Helping to Keep the Peace (Albeit Reluctantly): China's Recent Stance on Sovereignty and Multilateral Intervention. Pacific Affairs, 77(1): 927.

Chen, J. 2008. Explaining the Change in China's Attitude toward UN Peacekeeping: A Norm change Perspective. Journal of Contemporary China, 18(58):157173.

Choedon, Y. 2005. China's Stand on UN Peacekeeping Operations: Changing Priorities of Foreign Policy. China Report 41(1):39-57.

Fortna, Virginia Page. 2004. Does Peacekeeping Keep Peace? International Intervention and the Druation of Peace After Civil War. International Studies Quarterly, 48: 269-292.

Fortna, V.P. 2008. Does Peacekeeping Work? Shaping Belligerents' Choices after Civil War. New Jersey and Surrey: Princeton University Press. 
Fox, J. 2012. Lecture Notes: Unusual and Influential Data [Online]. Available: http://socserv.socsci.mcmaster.ca/jfox/Courses/soc740/lecture-7notes.pdf. [2012, May 16].

Gill, B. and Huang, Chin-hao. 2009. China's Expanding Role in Peacekeeping: Prospects and Policy Implications [Online]. Stockholm: SIPRI. Available: http://books.sipri.org/files/PP/SIPRIPP25.pdf. [2012, May 16].

Gill, B. and Reilly, J. 2000. Sovereignty, Intervention and Peacekeeping: The View from Beijing. Survival 42(3):41-59.

Gilligan, M. and Stedman, S.J. 2003. Where Do the Peacekeepers Go?. International Studies Review, 5(4):37-54.

Gleditsch, N.P., Wallensteen, P., Eriksson, M., Sollenberg, M. \& Håvard S. 2000. Armed Conflict 1946-2001: A new dataset. Journal of Peace Research, 39(5):615-637.

He, Yin. 2007. China's changing policy on UN peacekeeping operations. Stockholm: Institute for Security and Development Policy.

Hellström, J. 2009. Blue Berets Under the Red Flag: China in UN Peacekeeping System. Stockholm: Swedish Defence Research Agency.

Hirono, M. 2011. China's Charm Offensive and Peacekeeping: The Lessons of Cambodia - What Now for Sudan?. International Peacekeeping, 18 (3):328-343.

Hirono, M. and Lanteigne, M. 2011. Introduction: China and UN Peacekeeping. International Peacekeeping, 18(3):243-256.

Huang Chin-Hao. 2011. Principles and Praxis of China's Peacekeeping. International Peacekeeping, 18(3):257-270.

International Crisis Group. 2009. China's Growing Role in UN Peacekeeping (Asia Report $N^{\circ} 166$ ). Beijing/New York/Brussels: ICG. 


\section{AFRICAN \\ EAST-ASIAN \\ AFFAIRS \\ THE CHINA MONITOR}

International Monetary Fond, Direction of Trade Statistics (1988-2011).

Kleine-Ahlbrandt, S. and Small, A. 2008. China's New Dictatorship Diplomacy: Is Beijing Parting With Pariahs?. Foreign Affairs, 87(1):38-56.

Lacina, B. and Gleditsch, N.P. 2005. Monitoring Trends in Global Combat: A New Dataset of Battle Deaths. European Journal of Population , 21(2-3):145-166.

Lanteigne, M. 2011. A Change in Perspective: China's Engagement in the East Timor UN Peacekeeping Operations. International Peacekeeping, 18(3):313327.

Lawson, B.S. 2011. The Price of Peace: A Quantitative Analysis of Economic Interests and China's Involvement in United Nations Peacekeeping Operations. M.S. thesis, Georgetown University. Available: http:// repository.library.georgetown.edu/bitstream/handle/10822/553535/ lawsonBenjamin.pdf? sequence=1. [2012, May 16].

Lin-Greenberg, E. 2009. Blue Helmeted Dragons: Explaining China's Participation in United Nations Peace Operations. M.S. thesis, Massachussetts Institute of Technology. Available: http://dspace.mit.edu/handle/1721.1/53085. [2012, May 16].

Lynch, C. 2006. China Filling Void Left by West in U.N. Peacekeeping. The Wasshington Post, [Online] 24 November 2006. Available: http:// www.washingtonpost.com/wp-dyn/content/article/2006/11/23/

AR2006112301007.html. [2012, May 15].

Mullenbach, M. J. 2005. Deciding to Keep Peace: An Analysis of International Influences on the Establishment of Third-Party Peacekeeping Missions. International Studies Quarterly, 49(3):529-556.

Mulvenon, J. 2009. Chairman Hu and the PLA's "New Historic Missions". China Leadership Monitor, 27: 1-11. 
National Bureau of Statistics of China. China Statistical Yearbook (1996-2011). Available: http://www.stats.gov.cn/english/statisticaldata/yearlydata/. [2012, May 16].

Pang, Z. 2005. China's changing attitude to UN peacekeeping. International Peacekeeping, 12(1):87-104.

Ransom, I. 2008. U.N.'s Ban calls on China to be bigger peacemaker. Reuters, [Online] 01 July 2008. Available: http://uk.reuters.com/ article/2008/07/01/uk-china-ban-idUKPEK29161920080701. [2012, May $16]$.

Saferworld. 2011. China's growing role in African peace and security. [Online] Available: http://www.saferworld.org.uk/downloads/pubdocs/Chinas\% 20Growing\%20Role\%20in\%20African\%20Peace\%20and\% 20Security.pdf. [2012, May 15].

Staehle, S. 2008. China's Shifting Attitude towards United Nations Peacekeeping Operations. The China Quarterly, 195:631-655.

Talyor, I. 2008. The Future of China's Overseas Peacekeeping Operations. China Brief (8)6.

Tang, Y. 2002. Zhongguo yu Lianheguo Weihe Xingdong [China and United Nations Peacekeeping Operations]. World Economics and Politics 9:3944.

Thompson, D. 2005. Beijing's Participation in UN Peacekeeping Operations. China Brief 5(11).

Uppsala Conflict Data Program, UCDP Battle-Related Deaths Dataset v.5-2011 [Online]. Uppsala University. Available: www.ucdp.uu.se.

UN Department of Peacekeeping Operations. 2011. Ranking of Military and Police Contributions to UN Operations (Month of Report: 31-Dec-2011). 


\section{AFRICAN \\ EAST-ASIAN \\ AFFAIRS \\ THE CHINA MONITOR}

New York : UNDPKO. Available through: UN Peacekeeping Statistics http:// www.un.org/en/peacekeeping/contributors/2011/dec11_2.pdf [2012, May 16].

UN Department of Peacekeeping Operations. 2012. Financing Peacekeeping. [Online]. Available: http://www.un.org/en/peacekeeping/operations/ financing.shtml. [2012, May 16].

UN Department of Peacekeeping Operation, Peacekeeping Operation Timeline. [Online]. Available: http://www.un.org/en/peacekeeping/documents/ operationslist.pdf. [2012, May 18].

UN Radio. 2004. Annan Urges Greater Peacekeeping Role for China. [Online]. Available: www.unmultimedia.org/radio/english/detail/45480.html. [2012, May 16].

Velázquez, A.C.S. 2010. Why Some States Participate in UN Peace Missions While Others Do Not: An Analysis of Civil-Military Relations and Its Effects on Latin America's Contributions to Peacekeeping Operations. Security Studies, 19(1):160-195.

Wang, X and Zuo, S. 2010. Zhongguo Renmin Jiefangjun Canyu Lianheguo Weichi Heping Xindong de Lishi he Fazhan Qushi [History and Trend of the PLA's Participation in UN Peacekeeping Operations]. Military History, 5:46-51.

Wallensteen, P. 2011. Peace Research: Theory and Practice. Abingdon: Routledge.

$\mathrm{Wu}, \mathrm{Z}$. and Taylor, I. 2011. From refusal to engagement: Chinese contributions to peacekeeping in Africa. Journal of Contemporary African Studies, 29(2):137154.

Zhang, H. 2004. Toushi Zhongguo Canyu Lianheguo Weihe Xingdong [A survey on China's participation in UN Peacekeeping Operations]. Journal of Ideological and Theoretical Education, 9:46-49.

Zhang, H. 2009. Zhongguo Canyu Lianheguo Weihe Xingdong Shuping [Discussion 
on China's Participation in UN Peacekeeping Operations. Contemporary International Relations, 2:51-57.

Zhao, L. 2009. Zhongguo Canyu Lianheguo WeiHe Xindong de Leixing ji Diyu Fenxi [China in United Nations Peacekeeping Operations: Operational Types and Regions]. Journal of Contemporary Asia-Pacific Studies, 2:5572.

Zhao, L. 2011. Two Pillars of China's Global Peace Engagement Strategy: UN Peacekeeping and International Peacebuilding. International Peacekeeping, 29 (2): 344-362.

Zhong, L and Wang, J. 2006. Zhongguo dui Lianheguo Weichi Heping Xingdong de Renzhi he Canyu [China's Conception of and Participation in UN Peacekeeping Operation]. Contemporary China History Studies, 13(6):78-85.

Zhou, Q. and Zhang, J. 2007. Cong Guojia Anquanliyi de Jiaodu Kan Zhongguo dui Lianheguo Weihe Xingdong Renzhi de Gaibian [On Changes of China's Perception of the UN Peacekeeping Operations - A Perspective of National Security and Interest]. Contemporary World and Socialism, 5:56-60. 